\title{
Kinetic properties of ribulose bisphosphate carboxylase/oxygenase from Thiobacillus thyasiris, the putative symbiont of Thyasira flexuosa (Montagu), a bivalve mussel
}

\author{
C. M. CooK, ${ }^{1 *}$ T. Lanaras, ${ }^{1}$ A. P. Wood,${ }^{2}$ G. A. CodD $^{3}$ and D. P. Kelly ${ }^{2}$ \\ ${ }^{1}$ Department of Botany, University of Thessaloniki, P.O. Box 109, GR-540 06 Thessaloniki, Greece \\ ${ }^{2}$ Department of Biological Sciences, University of Warwick, Coventry, CV4 7AL, UK \\ ${ }^{3}$ Department of Biological Sciences, University of Dundee, Dundee, DD1 4HN, UK
}

(Received 2 November 1990; revised 5 March 1991; accepted 26 March 1991)

\begin{abstract}
Some kinetic properties of ribulose 1,5-bisphosphate (RuBP) carboxylase/oxygenase from Thiobacillus thyasiris, a marine, facultatively heterotrophic, sulphur-oxidizing bacterium and putative symbiont of Thyasira flexuosa (Montagu), a bivalve mussel, have been determined. The kinetic parameters for the $\mathrm{CO}_{2} / \mathrm{Mg}^{2+}$-activated enzyme were: $K_{\mathrm{m}}(\mathrm{RuBP}) 24.3 \mu \mathrm{M}, K_{\mathrm{m}}\left(\mathrm{CO}_{2}\right) 125.5 \mu \mathrm{M}, K_{\mathrm{m}}\left(\mathrm{O}_{2}\right) 900 \mu \mathrm{M}$ and $K_{\mathrm{m}}\left(\mathrm{Mg}^{2+}\right) 1.53 \mathrm{mM}$. The low $\mathrm{CO}_{2}$ affinity suggests that $T$. thyasiris may possess a $\mathrm{CO}_{2}$-concentrating mechanism. $\mathrm{RuBP}$ oxygenase activity was inhibited by increasing $\mathrm{CO}_{2}$ concentration. Divalent metal ions were essential for RuBP carboxylase activity; activity of the $\mathrm{Mg}^{2+}$-free enzyme could be restored by the addition of $\mathrm{Mg}^{2+}, \mathrm{Mn}^{2+}$ or $\mathrm{Ca}^{2+}$. The pH optimum was 7.8. The temperature optimum for $\mathrm{RuBP}$ carboxylase activity was $55^{\circ} \mathrm{C}$, although the enzyme rapidly lost activity at this temperature. An Arrhenius plot was biphasic, with a break at $40^{\circ} \mathrm{C}$. The activation energies were $55.5 \times 10^{3} \mathrm{~J}$ $\mathrm{mol}^{-1}$ and $32.9 \times 10^{3} \mathrm{~J} \mathrm{~mol}^{-1}$ over the temperature ranges $10-40{ }^{\circ} \mathrm{C}$ and $40-55{ }^{\circ} \mathrm{C}$, respectively. $Q_{10}$ was 2.12 for any $10{ }^{\circ} \mathrm{C}$ increment between $10-40^{\circ} \mathrm{C}$, and 1.47 between $40-55^{\circ} \mathrm{C}$. RuBP carboxylase activity was stable at $35^{\circ} \mathrm{C}$, the optimum growth temperature of $T$. thyasiris and at $7.5^{\circ} \mathrm{C}$, the temperature of the habitat of Thyasira flexuosa, but the activity was $40 \%$ and $3.5 \%$, respectively, of the potential activity at $55{ }^{\circ} \mathrm{C}$. RuBP carboxylase activity was stimulated by $\mathrm{NaCl}$ concentrations of up to $0.3 \mathrm{M}$, with a maximum (33\%), occurring between 0.1 and $0.2 \mathrm{M}-\mathrm{NaCl}$. At higher concentrations of $\mathrm{NaCl}(>0.3 \mathrm{M}) \mathrm{RuBP}$ carboxylase activity was inhibited.
\end{abstract}

\section{Introduction}

Symbioses between marine invertebrates and endosymbiotic chemoautotrophic sulphur bacteria are now well documented in several phyla of worms and in five families of bivalve molluscs, found in a variety of habitats where reduced chemical species are present (Cavanaugh, 1985; Southward, 1987). In members of the Pogonophora, gutless marine worms, the symbionts are internally localized in the trophosome, a highly vascularised organ, where they are supplied with oxygen and other metabolites (Southward \& Southward, 1988). In most molluscs, with the exception of the thyasirids, the bacteria are located in the epidermal cells of the gills (Southward, 1987). In thyasirids and some oligochaetous annelids, the bacteria are located under the cuticle of the epidermal cells (Southward, 1986). Epidermally located

Abbreviations: $\mathrm{RuBisCO}$, ribulose 1,5-bisphosphate carboxylase/ oxygenase; RuBP, ribulose 1,5-bisphosphate. bacteria are in close proximity to the external environment and the necessary metabolites $\mathrm{CO}_{2}, \mathrm{O}_{2}$ and sulphide.

It has been estimated that chemoautotrophic symbionts may contribute from $50-100 \%$ of the host carbon, either through the provision of extracellular products or by the digestion of the symbionts themselves (Southward, 1986, 1987). However, further investigation of the nutritional basis of the symbioses requires the identification and characterization of the symbionts. Their isolation in pure culture has proved difficult; however, the putative symbiont from Thyasira flexuosa (Montagu), a thyasirid bivalve mussel from a low-sulphide environment, has recently been isolated and characterized (Wood \& Kelly, 1989). The symbiont, Thiobacillus thyasiris, is a novel, marine, facultatively heterotrophic Thiobacillus unlike any previously described. Autotrophically grown cultures contained ribulose 1,5-bisphosphate carboxylase/oxygenase (RuBisCO; EC 4.1.1.39) and excreted up to $20 \%$ of their fixed carbon into the 
medium. These extracellular products would presumably be available for use by the host.

In view of the important role played by autotrophy in the nutrition of the animal host (Southward, 1987), it was of interest to examine the kinetic properties of the primary $\mathrm{CO}_{2}$-fixing enzyme, $\mathrm{RuBisCO}$. A wide species variation has been found in the kinetic properties of $\mathrm{RuBisCO}$, which appears to be determined partly by past evolutionary pressures and partly by the present physicochemical environment in which the enzyme functions (Yeoh et al., 1981; Jordan \& Ogren, 1981, 1983). Apart from several reports of RuBP carboxylase activity in symbiont-containing host tissue (see Southward, 1987) data on RuBisCO kinetics are limited to temperature optimum and $K_{\mathrm{m}}(\mathrm{RuBP})$, determined in extracts of symbiont-containing tissues (Fisher \& Hand, 1984; Williams et al., 1988). In this study, some kinetic properties of $\mathrm{RuBisCO}$ from $T$. thyasiris have been determined. To our knowledge, this is the first report on purified $\mathrm{RuBisCO}$ from an organism isolated from a marine invertebrate-chemoautotrophic bacterial symbiosis.

\section{Methods}

Growth of Thiobacillus thyasiris. T. thyasiris, deposited with the Deutsche Sammlung von Microorganismen, Braunschweig, FRG, (DSM 5322), was grown mixotrophically in chemostat culture at dilution rates of $0.012-0.038 \mathrm{~h}^{-1}$ on a medium described previously (Wood \& Kelly, 1989), containing thiosulphate ( $20 \mathrm{mM}$ ) and acetate (2 or $10 \mathrm{~mm})$ at $\mathrm{pH} 7.5$ and $30^{\circ} \mathrm{C}$, and gassed with $\mathrm{CO}_{2}$ in air $(2.5 \% \mathrm{v} / \mathrm{v})$. Cells were harvested by centrifugation at $23000 \mathrm{~g}$ for $10 \mathrm{~min}$ at $5{ }^{\circ} \mathrm{C}$, washed in $0.055 \mathrm{M}$-sodium phosphate buffer ( $\mathrm{pH} 8.0$ ) containing $0.43 \mathrm{M}-\mathrm{NaCl}$, recentrifuged, and stored at $-20^{\circ} \mathrm{C}$.

Preparation of cell-free extracts and purification of ribulose 1,5bisphosphate carboxylase/oxygenase (EC 4.1.1.39). The procedure, carried out at $4{ }^{\circ} \mathrm{C}$, was essentially that of Bowien (1977) with the following modifications. Deep-frozen $T$. thyasiris cells were resuspended in 3 vols isolation buffer ( $10 \mathrm{~mm}$-Tris, $0.5 \mathrm{~mm}$-EDTA-Na ${ }_{2}$, $50 \mathrm{~mm}-\mathrm{NaHCO}_{3}, 10 \mathrm{~mm}-\mathrm{MgCl}_{2}$ and $14.2 \mathrm{~mm}-2$-mercaptoethanol; $\mathrm{pH} 8.2)$. The cells were broken by sonication $(6 \times 30 \mathrm{~s})$ with an MSE Soniprep 150 at 26 amplitude microns and the resulting preparation was centrifuged at $40000 \mathrm{~g}$ for $1 \mathrm{~h}$. The supernatant was fractionated by additions of a saturated solution of $\left(\mathrm{NH}_{4}\right)_{2} \mathrm{SO}_{4}(\mathrm{pH} \mathrm{7.6)}$ and the bulk of the RuBP carboxylase activity was precipitated in the $30-70 \%$ saturated $\left(\mathrm{NH}_{4}\right)_{2} \mathrm{SO}_{4}$ fraction. This was resuspended in, and dialysed against, isolation buffer, and sedimented into linear $0.2 \mathrm{M}-0.8 \mathrm{M}$ sucrose gradients $(32 \mathrm{ml})$ by centrifugation in a swing-out rotor at $23000 \mathrm{~g}$ for $15 \mathrm{~h}$, in a minor modification of the method of Goldthwaite \& Bogorad (1971). Gradients were fractionated and the fractions ( $1 \mathrm{ml})$ monitored for protein and RuBP carboxylase activity. Those fractions containing peak activity were pooled, and dialysed against isolation buffer containing $10 \mathrm{~mm}$-Tris, $0.5 \mathrm{~mm}$-EDTA- $\mathrm{Na}_{2}, 10 \mathrm{~mm}-\mathrm{NaHCO}_{3}$, $5 \mathrm{mM}-\mathrm{MgCl}_{2}$ and $14.2 \mathrm{~mm}-2$-mercaptoethanol, $\mathrm{pH} 8 \cdot 2$. This preparation was used for the kinetic studies and showed a single protein band when analysed by native gel electrophoresis. The specific activity of the purified enzyme was $0.85 \mu \mathrm{mol} \mathrm{m^{-1 }}$ (mg protein) $)^{-1}$. Protein was determined according to the method of Bradford (1976). A slow loss of activity was observed on storage at $4^{\circ} \mathrm{C}$.
Assay of ribulose 1,5-bisphosphate carboxylase/oxygenase. RuBP carboxylase and RuBP oxygenase activities were measured essentially as described by Pierce et al. (1982). Enzyme $\left(0.38 \mathrm{mg} \mathrm{ml}^{-1}\right)$ was activated in the presence of 10 or $100 \mathrm{mM}$-Bicine, $0.5 \mathrm{~mm}$-EDTA-Na, $10 \mathrm{~mm}-\mathrm{NaHCO}_{3}, 5 \mathrm{~mm}-\mathrm{MgCl}_{2}$ and $1 \mathrm{~mm}-\mathrm{DTT}$ (pH 8.2) for $30 \mathrm{~min}$ at $30^{\circ} \mathrm{C}$, prior to assay in either carboxylase or oxygenase assays.

RuBP carboxylase activity was determined as the incorporation of $\left[{ }^{14} \mathrm{C}\right]$ bicarbonate into acid-stable products. The assay $(0.25 \mathrm{ml})$ contained $100 \mathrm{~mm}$-Bicine (pH 8.2), $0.5 \mathrm{~mm}-\mathrm{EDTA}-\mathrm{Na}_{2}, 30 \mathrm{~mm}-$ $\mathrm{NaH}^{14} \mathrm{CO}_{3}$ (specific radioactivity $3.7 \times 10^{3} \mathrm{~Bq} \mu \mathrm{mol}^{-1}$ ), $10 \mathrm{~mm}$ $\mathrm{MgCl}_{2}, 1.0 \mathrm{~mm}$-DTT and $0.5 \mathrm{~mm}$-RuBP. Assays (at $30^{\circ} \mathrm{C}$ ) were initiated either by activated enzyme or RuBP and terminated by the addition of $2 \mathrm{M}-\mathrm{HCl}$ (final concentration $0.57 \mathrm{M}$ ). Assay time was dependent on the amount of protein or the activity of the enzyme added. RuBP carboxylase activity was proportional to protein concentration (up to $0.16 \mathrm{mg} \mathrm{ml}^{-1}$ ) when assayed for $2 \mathrm{~min}$, indicating that protein concentration was the limiting factor in the assay. The gradient, corresponding to specific activity, was $0.7 \mu \mathrm{mol} \mathrm{min}^{-1}$ (mg protein) $)^{-1}$.

RuBP oxygenase activity was measured at $30^{\circ} \mathrm{C}$ using a Rank Pt-Ag oxygen electrode. The assay $(1 \mathrm{ml})$ contained $100 \mathrm{~mm}$-Bicine $(\mathrm{pH} 8 \cdot 2)$, $0.5 \mathrm{~mm}$-EDTA-Na $, 10 \mathrm{mM}-\mathrm{MgCl}_{2}, 1.0 \mathrm{~mm}$-DTT and $0.5 \mathrm{~mm}$-RuBP. Assays were initiated by the addition of activated enzyme. The final concentration in the assay of $\mathrm{NaHCO}_{3}$ carried over with the activated enzyme was $0.5 \mathrm{mM}$. Oxygen concentration in the assay was adjusted by gassing with either $100 \% \mathrm{~N}_{2}$ or $\mathrm{O}_{2}$

Kinetic parameters. RuBP carboxylase or oxygenase activity was measured over a range of substrate and cofactor concentrations; RuBP $(0.01-0.4 \mathrm{mM}), \mathrm{HCO}_{3}^{-}(0.4-12.4 \mathrm{~mm}), \mathrm{O}_{2}(0.1-0.9 \mathrm{mM})$ and $\mathrm{Mg}^{2+}(0.2-$ $2.0 \mathrm{~mm}$ ). Assays (in triplicate) were initiated with activated enzyme to give final protein concentrations of $0.075,0.015,0.019$ and $0.015 \mathrm{mg}$ $\mathrm{ml}^{-1}$, respectively, in the above experiments. Apparent $K_{\mathrm{m}}$ values were determined from double reciprocal plots (Lineweaver-Burk) or EadieHofstee plots.

To determine the apparent $K_{\mathrm{m}}\left(\mathrm{CO}_{2}\right)$, all solutions were freshly prepared in MilliQ-beaked water, and buffer was adjusted with $50 \%$ (w/v) $\mathrm{NaOH}$. Enzyme was activated with $\mathrm{H}^{14} \mathrm{CO}_{3}^{-}$and the carry over of $\mathrm{H}^{14} \mathrm{CO}_{3}^{-}$in the assay gave a final concentration of $0.4 \mathrm{mM}$. The concentration of $\mathrm{CO}_{2}$ at $\mathrm{pH} 8.2$ and $30^{\circ} \mathrm{C}$ was calculated using equations and constants (Buch, 1960) for zero ionic strength. The RuBP carboxylase activity of the enzyme used in the determination of apparent $K_{\mathrm{m}}\left(\mathrm{O}_{2}\right)$ was $57 \mathrm{nmol} \mathrm{CO}_{2} \min ^{-1}$ (mg protein) ${ }^{-1}$. The equilibrium concentration of oxygen in air-saturated water at a given temperature was calculated from the data of Truesdale et al. (1955).

Cofactor specificity. Chloride salts of the divalent metal ions $\mathrm{Ca}^{2+}$, $\mathrm{Co}^{2+}, \mathrm{Cu}^{2+}, \mathrm{Mg}^{2+}, \mathrm{Mn}^{2+}, \mathrm{Ni}^{2+}, \mathrm{Zn}^{2+}, \mathrm{Fe}^{2+}$ ) were prepared in $100 \mathrm{mM}-$ Bicine buffer, $\mathrm{pH} 8 \cdot 2$. RuBisCO free of metal ions was prepared by extensive dialysis against $10 \mathrm{~mm}$-Tris ( $\mathrm{pH} 8.2$ ) containing $0.5 \mathrm{~mm}$ EDTA- $\mathrm{Na}_{2}$ and 14.2 mM-2-mercaptoethanol. The protein concentration was determined after dialysis. RuBP carboxylase activity was $139.6 \mathrm{nmol} \mathrm{min} \mathrm{min}^{-1}$ (mg protein) $)^{-1}$ before dialysis, and was not detectable after dialysis.

Enzyme free of metal ions was incubated in assay mixture (not containing $\mathrm{MgCl}_{2}$ ) containing a final concentration of $20 \mathrm{mM}$ of one of each of the metal ions listed, for $30 \mathrm{~min}$ at $30^{\circ} \mathrm{C}$. Assays were initiated with $\mathrm{RuBP}$, terminated after $5 \mathrm{~min}$, and the protein concentration in the assay was $0.051 \mathrm{mg} \mathrm{ml}^{-1}$. The RuBP carboxylase activity recovered in the presence of $\mathrm{MgCl}_{2}$ was $57.2 \mathrm{nmol} \mathrm{m^{-1 }}$ (mg protein) $)^{-1} ; 41 \%$ of the activity prior to dialysis.

pH optimum. RuBP carboxylase activity was assayed (in triplicate) in Bicine (100 mM) over the $\mathrm{pH}$ range 7.4-9.2 and in HEPES (100 mM) over the $\mathrm{pH}$ range $7 \cdot 0-8 \cdot 2$, in increments of $0.2 \mathrm{pH}$ unit. Assays were initiated with enzyme activated at $\mathrm{pH} 8.2$ and the concentration of 
buffer carried over into the assay was $1 \mathrm{~mm}$. Substrates were saturating at each $\mathrm{pH}$, and the protein concentration in the assay was $0.038 \mathrm{mg}$ $\mathrm{ml}^{-1}$.

Temperature optimum. RuBP carboxylase activity was assayed (in duplicate) over the temperature range $5-75^{\circ} \mathrm{C}$, in increments of $5^{\circ} \mathrm{C}$. Assays were initiated with enzyme activated at $30^{\circ} \mathrm{C}$ and terminated after $2 \mathrm{~min}$, thus minimizing the effects of thermal denaturation during the assay. The protein concentration in the assay was $0.075 \mathrm{mg} \mathrm{ml}^{-1}$.

Thermostability. RuBisCO was incubated at 55,35 and $7.5^{\circ} \mathrm{C}$ under activating conditions. Samples were removed at intervals and incubated for $5 \mathrm{~min}$ at $30^{\circ} \mathrm{C}$ prior to assay. Enzyme incubated at $55^{\circ} \mathrm{C}$ was cooled immediately on ice at the given time, before incubation at $30{ }^{\circ} \mathrm{C}$ and assay. Assays were initiated with RuBP and terminated after $5 \mathrm{~min}$. The protein concentration in the assay was $0.075 \mathrm{mg} \mathrm{ml}^{-1}$.

Effect of $\mathrm{NaCl}$. RuBP carboxylase activity was measured in the presence of $\mathrm{NaCl}$ over a range of concentrations $(0-0 \cdot 3 \mathrm{M}$ and $0-1.0 \mathrm{M})$. Assays were initiated by the addition of activated enzyme (final concentration in assay $0.038 \mathrm{mg} \mathrm{ml}^{-1}$ ) and were terminated after $10 \mathrm{~min}$.

\section{Results}

The apparent $K_{\mathrm{m}}$ values for the substrates $\mathrm{RuBP}, \mathrm{CO}_{2}$ and $\mathrm{O}_{2}$, and for the cofactor $\mathrm{Mg}^{2+}$ were determined for $\mathrm{CO}_{2} / \mathrm{Mg}^{2+}$-activated $\mathrm{RuBisCO}$ from $T$. thyasiris (Table 1). In accordance with the competitive nature of the substrates $\mathrm{CO}_{2}$ and $\mathrm{O}_{2}$ in other RuBisCOs, where $K_{\mathrm{m}}\left(\mathrm{CO}_{2}\right)$ carboxylase $=K_{\mathrm{i}}\left(\mathrm{CO}_{2}\right)$ oxygenase (Laing et al. 1974), increasing concentrations of added $\mathrm{HCO}_{3}^{-}$inhibited $T$. thyasiris RuBP oxygenase activity. Fifty percent inhibition was observed at $3 \cdot 2 \mathrm{mM}-\mathrm{HCO}_{3}^{-}\left(41 \cdot 3 \mu \mathrm{M}-\mathrm{CO}_{2}\right)$ (pH $8 \cdot 2,30^{\circ} \mathrm{C}$ and atmospheric oxygen concentration).

Divalent metal ions were essential for RuBP carboxylase activity, since enzyme activity was not detectable when enzyme was dialysed free of $\mathrm{Mg}^{2+}$. Activity ( $41 \%$ of the initial activity) was recovered after the readdition of $20 \mathrm{mM}-\mathrm{MgCl}_{2}$. The addition of the chloride salts of $\mathrm{Mn}^{2+}$ and $\mathrm{Ca}^{2+}(20 \mathrm{mM})$ to the $\mathrm{Mg}^{2+}$-free enzyme supported 12.8 and $5.4 \%$ respectively, of the RuBP carboxylase activity recovered in the presence of $\mathrm{Mg}^{2+}$. The other divalent metal ions tested $\left(\mathrm{Co}^{2+}, \mathrm{Cu}^{2+}, \mathrm{Ni}^{2+}\right.$,

Table 1. Kinetic parameters determined for $\mathrm{CO}_{2} / \mathrm{Mg}^{2+}$ activated Thiobacillus thyasiris $R$ RBP carboxylase and oxygenase activities

\begin{tabular}{|c|c|c|c|c|}
\hline \multirow[b]{2}{*}{ Parameter } & \multicolumn{3}{|c|}{$\begin{array}{l}\text { RuBP carboxylase } \\
\text { activity }\end{array}$} & \multirow{2}{*}{$\begin{array}{c}\text { RuBP oxygenase } \\
\text { activity } \\
\mathrm{O}_{2}\end{array}$} \\
\hline & RuBP & $\mathbf{M g}^{2+}$ & $\mathrm{CO}_{2}$ & \\
\hline \multirow{2}{*}{ 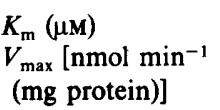 } & $24 \cdot 3$ & 1530.0 & $125 \cdot 5$ & $900 \cdot 0$ \\
\hline & $331 \cdot 7$ & $262 \cdot 6$ & 164.8 & $336 \cdot 0$ \\
\hline
\end{tabular}

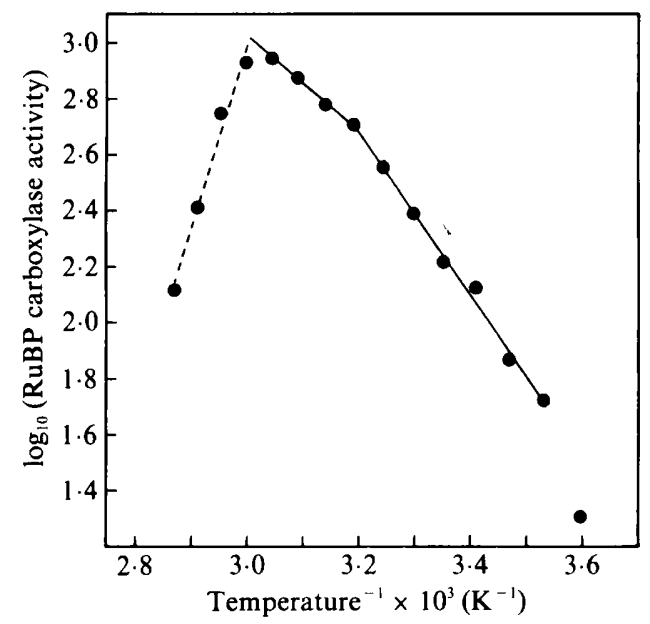

Fig. 1. Arrhenius plot for Thiobacillus thyasiris RuBP carboxylase activity. A break occurs at $40^{\circ} \mathrm{C}$. Enzyme activity was expressed as $\mathrm{nmol} \mathrm{min}^{-1}\left(\mathrm{mg}^{-1} \text { protein }\right)^{-1}$.

$\mathrm{Zn}^{2+}, \mathrm{Fe}^{2+}$ ) were ineffective in restoring the activity of the $\mathrm{Mg}^{2+}$-free enzyme.

The relationship between RuBP carboxylase activity and $\mathrm{pH}$ was broad over the $\mathrm{pH}$ range $7 \cdot 0-9 \cdot 0$, with a $20 \%$ loss of activity having occurred at $\mathrm{pH} 7.0$ and $\mathrm{pH} 8.8$. The optimum $\mathrm{pH}$ for activity was $7 \cdot 8$. The relationship between RuBP carboxylase activity and temperature was fairly sharp, with an optimum occurring at $55^{\circ} \mathrm{C}$. Above $55^{\circ} \mathrm{C}$, the decline in activity was quite rapid, reflecting the increasing influence of temperature on enzyme denaturation relative to the increase in reaction rate.

The activation energy $\left(E_{\mathrm{a}}\right)$ for the RuBP carboxylase reaction was determined from an Arrhenius plot and a break occurred at $40^{\circ} \mathrm{C}$ (Fig. 1). Over the temperature range $10-40^{\circ} \mathrm{C}, E_{\mathrm{a}}$ was $55.5 \times 10^{3} \mathrm{~J} \mathrm{~mol}^{-1}$ and $Q_{10} 2.12$ (for any $10^{\circ} \mathrm{C}$ increment) and over the temperature range $40-55^{\circ} \mathrm{C}, E_{\mathrm{a}}$ was $32.9 \times 10^{3} \mathrm{~J} \mathrm{~mol}^{-1}$ and $Q_{10} 1.47$ (for any $10^{\circ} \mathrm{C}$ increment).

The thermostability of $T$. thyasiris $\mathrm{RuBisCO}$ was investigated (Fig. 2). Despite the relatively high temperature optimum, RuBP carboxylase activity was unstable when incubated for prolonged periods at $55^{\circ} \mathrm{C}$. Incubation at $55^{\circ} \mathrm{C}$ for 10 min reduced RuBP carboxylase activity by $50 \%$, and after $30 \mathrm{~min}$ no activity was detected. Enzyme activity was fairly stable to incubation at $35^{\circ} \mathrm{C}$, the temperature optimum for the growth of the symbiont $T$. thyasiris as a free-living organism, at which about $10 \%$ of the RuBP carboxylase activity was lost over a $2.5 \mathrm{~h}$ period. At $7.5^{\circ} \mathrm{C}$, the temperature of the habitat in which the bivalve Thyasira flexuosa is found, the RuBP carboxylase activity remained unchanged over the same period. However, at $35^{\circ} \mathrm{C}$ and $7.5^{\circ} \mathrm{C}$, RuBP carboxylase activity represented only $40 \%$ and $3.5 \%$, respectively, of the potential activity at $55^{\circ} \mathrm{C}$. 


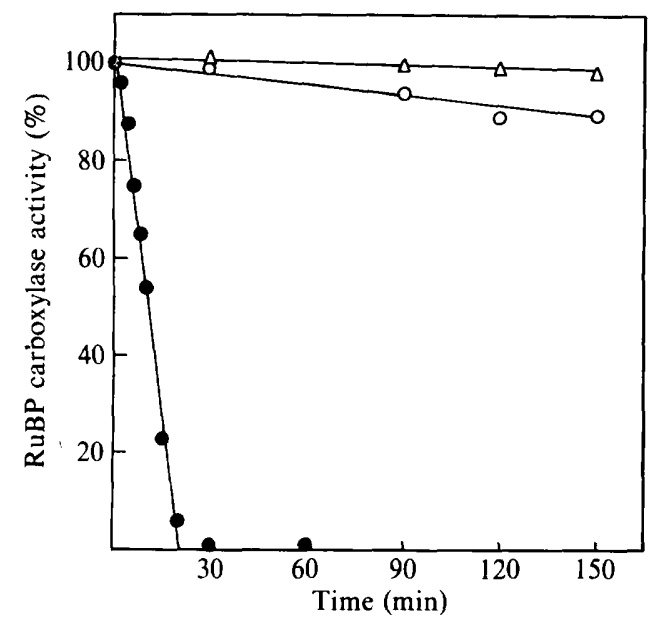

Fig. 2. Thermostability of Thiobacillus thyasiris RuBP carboxylase activity at $55^{\circ} \mathrm{C}(0), 35^{\circ} \mathrm{C}(O)$ and $7.5^{\circ} \mathrm{C}(\triangle)$. See Methods for experimental details. The initial RuBP carboxylase activity was $0 \cdot 112 \mu \mathrm{mol} \mathrm{min}^{-1}$ (mg protein) $)^{-1}$.

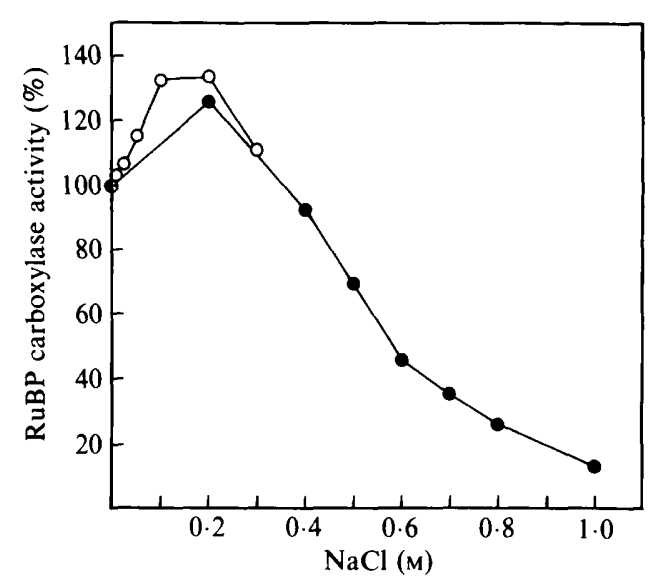

Fig. 3. The effect of $\mathrm{NaCl}$ on Thiobacillus thyasiris $\mathrm{RuBP}$ carboxylase activity over the concentration ranges 0 to $0.3 \mathrm{M}(O)$ and 0 to $1.0 \mathrm{M}(O)$. The initial RuBP carboxylase activities, in the absence of added $\mathrm{NaCl}$, were 0.070 and $0.061 \mu \mathrm{mol} \mathrm{min}^{-1}$ (mg protein) $)^{-1}$, respectively.

T. thyasiris was found to be slightly halophilic when grown autotrophically on thiosulphate, requiring about $0.5 \mathrm{M}-\mathrm{NaCl}$, and extremely halotolerant when grown on acetate, tolerating up to $3.0 \mathrm{M}-\mathrm{NaCl}$ (Wood \& Kelly, 1989). The effect of $\mathrm{NaCl}$ concentration on $\mathrm{RuBP}$ carboxylase activity was examined. $\mathrm{NaCl}$ concentrations of up to $0.3 \mathrm{M}$ in the assay stimulated activity, with a maximum stimulation of $33 \%$ occurring between $0 \cdot 1$ $0.2 \mathrm{M}-\mathrm{NaCl}$ (Fig. 3). At $\mathrm{NaCl}$ concentrations greater than $0.3 \mathrm{M}, \mathrm{RuBP}$ carboxylase activity was inhibited (Fig. 3). At $0.58 \mathrm{M}-\mathrm{NaCl}$ carboxylase activity was $50 \%$; however, even at $1.0 \mathrm{M}-\mathrm{NaCl}, 13 \%$ of the original activity was still detectable.

\section{Discussion}

A wide variation has been observed in the kinetic properties, primarily of $K_{\mathrm{m}}\left(\mathrm{CO}_{2}\right)$ and $K_{\mathrm{m}}\left(\mathrm{O}_{2}\right)$, of $\mathrm{RuBisCO}$ isolated from phylogenetically diverse sources (Yeoh et al., 1981; Jordan \& Ogren, 1981, 1983). An increased affinity of the enzyme for $\mathrm{CO}_{2}$ in more advanced photosynthetic organisms has been seen as an adaptation to a decrease in atmospheric $\mathrm{CO}_{2}$ and increase in $\mathrm{O}_{2}$ during the evolution of photosynthesis (Yeoh et al., 1981; Jordan \& Ogren, 1981, 1983). A correlation has also been observed between the possession of a $\mathrm{CO}_{2}$-concentrating mechanism, as found in many cyanobacteria and algae, and $\mathrm{C}_{4}$ plants, and a $\mathrm{RuBisCO}$ with low $\mathrm{CO}_{2}$ affinity (Yeoh et al., 1981). The value of $K_{\mathrm{m}}\left(\mathrm{CO}_{2}\right)$ determined for $T$. thyasiris $\mathrm{RuBisCO}$ $(125.5 \mu \mathrm{M})$ demonstrated that the enzyme had a low affinity for $\mathrm{CO}_{2}$ similar $(80-290 \mu \mathrm{M})$ to values determined for cyanobacterial RuBisCOs (Badger, 1980; Yeoh et al., 1981; Jordan \& Ogren, 1981), and suggests that $T$. thyasiris may possess a $\mathrm{CO}_{2}$-concentrating mechanism which maintains high internal $\mathrm{CO}_{2}$ levels at the site of $\mathrm{CO}_{2}$ fixation. Values of $K_{\mathrm{m}}\left(\mathrm{CO}_{2}\right)$ for other Thiobacillus RuBisCOs are few and varied (values converted to $\mathrm{CO}_{2}$ from $\mathrm{HCO}_{3}^{-}$concentration according to Buch, 1960): T. novellus, $147 \mu \mathrm{M}$ (McCarthy \& Charles, 1975); T. versutus (formerly Thiobacillus A2), $52.5 \mu \mathrm{M}$ (Charles \& White, 1976a); and T. neapolitanus, $18.7 \mu \mathrm{M}$ (Snead \& Shively, 1978). These values may reflect the diverse nutritional capacities, methods of acquisition of inorganic carbon, or the presence or absence of carboxysomes (inclusion bodies containing $\mathrm{RuBisCO}$ ).

Species-dependent variation in the affinity of RuBis$\mathrm{CO}$ for $\mathrm{O}_{2}$ was observed by Jordan \& Ogren (1981). The $T$. thyasiris $\mathrm{RuBisCO}$ demonstrated a low affinity for $\mathrm{O}_{2}\left[K_{\mathrm{m}}\left(\mathrm{O}_{2}\right) 900 \mu \mathrm{M}\right]$, similar $(990-1220 \mu \mathrm{M})$ to values determined for cyanobacterial RuBisCOs (Badger, 1980; Jordan \& Ogren, 1981), and represents the first report of $K_{\mathrm{m}}\left(\mathrm{O}_{2}\right)$ for a Thiobacillus enzyme. The low affinities for both $\mathrm{CO}_{2}$ and $\mathrm{O}_{2}$ of $T$. thyasiris and cyanobacterial $\mathrm{RuBisCOs}$ may reflect the common aerobic, prokaryotic nature of these organisms. $T$. thyasiris probably experiences conditions almost identical to the external environment (low $\mathrm{CO}_{2}$ and high $\mathrm{O}_{2}$ ) in the symbiosis, being located under the cuticle of the epidermal gill cells. The low $\mathrm{O}_{2}$ affinity would be advantageous under aerobic conditions. Symbiont RuBisCOs may exhibit different $K_{\mathrm{m}}\left(\mathrm{CO}_{2}\right)$ and $K_{\mathrm{m}}\left(\mathrm{O}_{2}\right)$ values, depending on their intracellular location and the ambient $\mathrm{CO}_{2}$ and $\mathrm{O}_{2}$ concentration in the surrounding host tissue. There is evidence that low levels of free $\mathrm{O}_{2}$ are in fact maintained in the vicinity of some symbionts. It has been proposed that pigment granules and an epithelium rich in 
Table 2. Parameters of temperature, and activation energies of ribulose 1,5-bisphosphate carboxylase/oxygenase from various microorganisms

\begin{tabular}{lccccl}
\hline \hline & $\begin{array}{c}\text { RuBisCO } \\
\text { temperature } \\
\text { optimum } \\
\left({ }^{\circ} \mathrm{C}\right)\end{array}$ & $\begin{array}{c}\text { Break } \\
\text { temperature } \\
\left({ }^{\circ} \mathrm{C}\right)\end{array}$ & $\begin{array}{c}\text { Activation } \\
\text { energy } \\
\left(\mathrm{kJ} \mathrm{mol}^{-1}\right)\end{array}$ & $\begin{array}{c}\text { Temperature } \\
\text { range } \\
\left({ }^{\circ} \mathrm{C}\right)\end{array}$ & \multicolumn{1}{c}{ Reference } \\
\hline Thiobacillus thyasiris & 55 & 40 & $55 \cdot 5$ & $10-40$ & This study \\
& & & $32 \cdot 9$ & $40-55$ & \\
Thiobacillus novellus & 50 & $40-50$ & 78.9 & $20-40$ & McCarthy \& Charles (1975) \\
& & & $37 \cdot 1$ & $40-50$ & \\
Thiobacillus versutus & 50 & 29 & $51 \cdot 6$ & $10-29$ & Charles \& White (1976b) \\
(formally A2) & & & $4 \cdot 4$ & $29-50$ & \\
Anabaena variabilis & - & - & $65 \cdot 3$ & $15-40$ & Badger (1980) \\
Cyanidium caldarium & 42.5 & 36 & 83.6 & $20-36$ & Ford (1979) \\
& & & $15 \cdot 2$ & $36-45$ & Ford (1979) \\
Chlorella spp. & 35 & 20 & 65.9 & $2 \cdot 5-20$ & Ford \\
& & & $5 \cdot 8$ & $20-30$ & \\
\hline \hline
\end{tabular}

mitochondria play an $\mathrm{O}_{2}$-scavenging role in the protection of $\mathrm{O}_{2}$-sensitive enzymes in the bacteriocytes of Lucina floridana, a bivalve mollusc (Fisher \& Hand, 1984). In the vestimentiferan pogonophore, Riftia pachyptila, $\mathrm{O}_{2}$ is bound to haemoglobin thereby protecting the symbionts from $\mathrm{O}_{2}$ inhibition of $\mathrm{CO}_{2}$-fixation (Fisher et al., 1989).

Although taxonomic patterns have been observed in $K_{\mathrm{m}}(\mathrm{RuBP})$ values, there was no correlation with $K_{\mathrm{m}}\left(\mathrm{CO}_{2}\right)$, photosynthetic pathway or natural habitat, with a wide variation in values occurring within any one phylum (Yeoh et al., 1981). The $K_{\mathrm{m}}(\mathrm{RuBP})$ value determined for $T$. thyasiris $\mathrm{RuBisCO}(24.3 \mu \mathrm{M})$ is comparable to values from Anabaena variabilis (Badger, 1980 ) and spinach (Yeoh et al., 1981). $K_{\mathrm{m}}(\mathrm{RuBP})$ values for RuBisCO from sulphur-oxidizing bacteria show some variation: $T$. novellus, $14.8 \mu \mathrm{M}$ (McCarthy \& Charles, 1975); T. neapolitanus, $92 \mu \mathrm{M}$ (Snead \& Shively, 1978); $T$. versutus, $122 \mu \mathrm{M}$ (Charles \& White, 1976a); and $65 \mu \mathrm{M}$ for the symbiont of $R$. pachyptila (Williams et al., 1988), but all fall within the range $(10-136 \mu \mathrm{M})$ exhibited by terrestrial versions of the enzyme (Yeoh et al., 1981). In contrast, the $K_{\mathrm{m}}(\mathrm{RuBP})$ for RuBisCO of the symbiont of L. floridana was reported to be $380 \mu \mathrm{M}$ (Fisher \& Hand, 1984).

In nature, $\mathrm{Mg}^{2+}$ plays a dual role in the activation and catalysis of RuBisCO (Miziorko \& Lorimer, 1983). The $K_{\mathrm{m}}\left(\mathrm{Mg}^{2+}\right)$ for catalysis was $1.53 \mathrm{mM}$ for $T$. thyasiris $\mathrm{RuBisCO}$. For other Thiobacillus RuBisCOs, the following values have been reported: $T$. novellus, $0.61 \mathrm{mM}$ (McCarthy \& Charles, 1975); T. versutus, $0.02 \mathrm{mM}$ (Charles \& White, 1976a); and T. neapolitanus, $0.59 \mathrm{mM}$ (Snead \& Shively, 1978). Divalent metal ions were essential for $T$. thyasiris RuBP carboxylase activity and $\mathrm{Mg}^{2+}$ was partially replaceable by $\mathrm{Mn}^{2+}$ and $\mathrm{Ca}^{2+}$. RuBisCOs appear to vary in their ability to substitute $\mathrm{Mg}^{2+}$ with other divalent metal ions such as $\mathrm{Mn}^{2+}, \mathrm{Co}^{2+}$ and $\mathrm{Ni}^{2+}$ (Miziorko \& Lorimer, 1983). Among the other Thiobacillus enzymes examined, $T$. versutus RuBP carboxylase activity was supported by $\mathrm{Mg}^{2+}$ and $\mathrm{Mn}^{2+}$ (Charles \& White, 1976a), while the enzymes from $T$. novellus (McCarthy \& Charles, 1975) and T. neapolitanus (Snead \& Shively, 1978) were specific for $\mathrm{Mg}^{2+}$.

The $\mathrm{pH}$ optimum of 7.8 for $T$. thyasiris RuBP carboxylase activity is consistent with the range 7.8-8.2 determined for other RuBisCOs (Charles \& White, 1976a; Badger, 1980). The temperature optimum of $T$. thyasiris $\mathrm{RuBisCO}\left(55^{\circ} \mathrm{C}\right)$ is consistent with the temperature optima reported for other Thiobacillus RuBisCOs (Table 2), but higher than those from the thermophiles Cyanidium caldarium $\left(42^{\circ} \mathrm{C}\right)$ (Ford, 1979) and Chromatium tepidum $\left(50^{\circ} \mathrm{C}\right)($ Heda \& Madigan, 1988). This is not indicative of a thermophilic characteristic since whereas the Cyanidium and Chromatium enzymes were stable at their temperature optima, $T$. thyasiris $\mathrm{RuBisCO}$ was not. Many RuBisCOs examined have demonstrated a biphasic Arrhenius plot (Table 2), which has been associated with a conformational change in the enzyme molecule. The activation energies determined for $T$. thyasiris $\mathrm{RuBisCO}$ are similar to those reported for other Thiobacillus RuBisCOs (Table 2).

$T$. thyasiris is slightly halophilic and extremely halotolerant, depending on growth conditions (Wood \& Kelly, 1989). The stimulation of $T$. thyasiris RuBP carboxylase activity in vitro by up to $0.3 \mathrm{M}-\mathrm{NaCl}$ is unlike the response to $\mathrm{NaCl}$ reported for other $\mathrm{RuBisCOs}$ examined to date, where $\mathrm{NaCl}$ has proved inhibitory even to the enzyme from halophiles (Charles \& White, 1976a; Tabita \& McFadden, 1976; Weber et al., 1977; Takabe et al., 1984). Although inhibited by $0.3 \mathrm{M}-\mathrm{NaCl}$ and above, $T$. thyasiris $\mathrm{RuBisCO}$ demonstrated a greater tolerance to $\mathrm{NaCl}$ than other RuBisCOs. It is not evident whether low $\mathrm{NaCl}$ concentrations are required for $T$. thyasiris RuBisCO stability or activity, or both. $\mathrm{NaCl}$ 
$(0.3 \mathrm{M})$ has been shown to stabilize the quaternary structure of Aphanothece halophytica $\mathrm{RuBisCO}$ in vitro; however, enzyme activity was drastically inhibited (Takabe et al., 1984). The stimulation of $T$. thyasiris $\mathrm{RuBP}$ carboxylase activity in vitro by $\mathrm{NaCl}$ may reflect the in vivo intracellular level of $\mathrm{Na}^{+}$or the cytoplasmic ionic strength, or may mimic the effect of other intracellular compounds. A similar pattern of $\mathrm{NaCl}$ stimulation and inhibition has been reported for glutamine synthetase from the halotolerant cyanobacterium Synechocystis sp. DUN52, where maximum stimulation occurred at $0.3 \mathrm{M}-\mathrm{NaCl}$ in vitro and the intracellular $\mathrm{Na}^{+}$ concentration was $0.145 \mathrm{M}$ (Warr et al., 1984).

This determination of some kinetic properties of RuBisCO from $T$. thyasiris represents the first report on the purified enzyme from a symbiotic Thiobacillus. The data presented will prove valuable in comparative studies of the kinetic properties of $\mathrm{RuBisCO}$ from other symbionts of marine invertebrate-chemoautotrophic bacterial symbioses and free-living chemoautotrophic bacteria. Variations arising from the ambient $\mathrm{CO}_{2}$ and $\mathrm{O}_{2}$ concentrations experienced by the bacterial symbiont or free-living bacteria, will be of particular interest with respect to the nutritional bases of the symbioses.

T. Lanaras wishes to thank the British Council for the award of a long-term Research Fellowship (SAL/2510). A. P. Wood acknowledges support from the Leverhulme Trust.

\section{References}

BADGER, M. R. (1980). Kinetic properties of ribulose 1,5-bisphosphate carboxylase/oxygenase from Anabaena variabilis. Archives of Biochemistry and Biophysics 201, 247-254.

Bowien, B. (1977). D-Ribulose 1,5-bisphosphate carboxylase from Paracoccus denitrificans. FEMS Microbiology Letters 2, 263-266.

BRADFORD, M. M. (1976). A rapid and sensitive method for the quantitation of microgram quantities of protein utilizing the principle of protein-dye binding. Analytical Biochemistry 72, 248254.

BuCH, K. (1960). Dissoziation der kohlensaure, gleichgewichte und puffersysteme. In Handbuch der Pflanzenphysiologie, vol. 1, pp. 1-11. Edited by W. Ruhland. Berlin: Springer-Verlag.

Cavanaugh, C. M. (1985). Symbioses of chemoautotrophic bacteria and marine invertebrates from hydrothermal vents and reducing sediments. Bulletin of the Biological Society of Washington 6, 373-388.

Charles, A. M. \& White, B. (1976a). Ribulose bisphosphate carboxylase from Thiobacillus A2. Its purification and properties. Archives of Microbiology 108, 195-202.

Charles, A. M. \& White, B. (1976b). Physical properties and metabolite regulation of ribulose bisphosphate carboxylase from Thiobacillus A2. Archives of Microbiology 108, 203-209.

FISHER, M. R. \& HAND, S. C. (1984). Chemoautotrophic symbionts in the bivalve Lucina floridana from seagrass beds. Biological Bulletin $167,445-459$.

Fisher, C. R., Childress, J. J. \& Minnich, E. (1989). Autotrophic carbon fixation by the chemoautotrophic symbionts of Riftia pachyptila. Biological Bulletin 177, 372-385.

FORD, T. W. (1979). Ribulose 1,5-bisphosphate carboxylase from the thermophilic, acidophilic alga, Cyanidium caldarium (Geitler). Purification, characterisation and thermostability of the enzyme. Biochimica et Biophysica Acta 569, 239-248.

Goldthwarte, J. J. \& Bogorad, L. (1971). A one-step method for the isolation and determination of leaf ribulose-1,5-diphosphate carboxylase. Analytical Biochemistry 41, 57-66.

HedA, G. D. \& Madigan, M. T. (1988). Thermal properties and oxygenase activity of ribulose-1,5-bisphosphate carboxylase from the thermophilic purple bacterium, Chromatium tepidum. FEMS Microbiology Letters 51, 45-50.

JoRdAN D. B. \& OGREN, W. L. (1981). Species variation in the specificity of ribulose bisphosphate carboxylase/oxygenase. Nature, London 291, 513-515.

JORDAN, D. B. \& OGREN, W. L. (1983). Species variation in kinetic properties of ribulose 1,5-bisphosphate carboxylase/oxygenase. Archives of Biochemistry and Biophysics 227, 425-433.

LAING, W. A., OgREN, W. L. \& HaGEMaN, R. H. (1974). Regulation of soybean net photosynthetic $\mathrm{CO}_{2}$ fixation by the interaction of $\mathrm{CO}_{2}$, $\mathrm{O}_{2}$ and ribulose 1,5-bisphosphate carboxylase. Plant Physiology 54, 678-685.

MCCarthy, J. T. \& Charles, A. M. (1975). Properties and regulation of ribulose diphosphate carboxylase from Thiobacillus novellus. Archives of Microbiology 105, 51-59.

MizIORKo, H. M. \& LoRIMER, G. H. (1983). Ribulose-1,5-bisphosphate carboxylase-oxygenase. Annual Review of Biochemistry 52, 507-535.

Pierce, J., McCurRy, S. D., Mulligan, R. M. \& Tolbert, N. E. (1982). Activation and assay of ribulose-1,5-bisphosphate carboxylase/oxygenase. In Methods in Enzymology, vol. 89, pp. 47-55. Edited by W. A. Wood. New York: Academic Press.

SNEAD, R. M. \& SHIVEly, J. M. (1978). D-Ribulose-1,5-bisphosphate carboxylase from Thiobacillus neapolitanus. Current Microbiology 1 , 309-314.

SoUTHWARD, E. C. (1986). Gill symbionts in thyasirids and other bivalve molluscs. Journal of the Marine Biological Association of the United Kingdom 66, 889-914.

SOUTHWARD, E. C. (1987). Contribution of symbiotic chemoautotrophs to the nutrition of benthic invertebrates. In Microbes in the Sea, pp. 83-118. Edited by M. A. Sleigh. Chichester: Ellis Horwood.

SouthWARD, A. J. \& SouthWARD, E. C. (1988). Pogonophora: Tubeworms dependent on endosymbiotic bacteria. Animal and Plant Sciences 1, 203-207.

TABITA, F. R. \& MCFAdDEN, B. A. (1976). Molecular and catalytic properties of ribulose 1,5-bisphosphate carboxylase from the photosynthetic extreme halophile Ectothiorhodospira halophila. Journal of Bacteriology 126, 1271-1277.

TAKaBE, T., RaI, A. N. \& AkAzaWA, T. (1984). Interaction of constituent subunits in ribulose 1,5-bisphosphate carboxylase from Aphanothece halophytica. Archives of Biochemistry and Biophysics 229, 202-211.

Truesdale, G. A., Downing, A. L. \& Lowden, G. F. (1955). The solubility of oxygen in pure water and seawater. Journal of Applied Chemistry 5, 53-62.

WARR, S. R. C., ReEd, R. H. \& STeWarT, W. D. P. (1984). Osmotic adjustment of cyanobacteria: the effects of $\mathrm{NaCl}, \mathrm{KCl}$, sucrose and glycine betaine on glutamine synthetase activity in a marine and halotolerant strain. Journal of General Microbiology 130, 2169-2175.

Weber, D. J., ANdersen, W. R., Hess, S., Hansen, D. J. \& Gunasekaran, M. (1977). Ribulose-1,5-bisphosphate carboxylase from plants adapted to extreme environments. Plant and Cell Physiology 18, 693-699.

Williams, C. A., Nelson, D. C., Farah, B. A., Jannasch, H. W. \& SHIVELY, J. M. (1988). Ribulose bisphosphate carboxylase of the procaryotic symbiont of a hydrothermal vent tube-worm: kinetics, activity and gene hybridization. FEMS Microbiology Letters 50, 107112.

WoOD, A. P. \& Kelly, D. P. (1989). Isolation and physiological characterisation of Thiobacillus thyasiris sp. nov., a novel marine facultative autotroph and the putative symbiont of Thyasira flexuosa. Archives of Microbiology 152, 160-166.

YeOH, H.-H., BADGER, M. R. \& WATSON, L. (1981). Variations in kinetic properties of ribulose-1,5-bisphosphate carboxylases among plants. Plant Physiology 67, 1151-1155. 